\title{
CREATION THROUGH HIEROGLYPHS: THE COSMIC GRAMMATOLOGY OF ANCIENT EGYPT
}

\author{
Jan Assmann
}

\section{Creation and Cosmogony}

There are two fundamental models of conceiving the origin of the world, an intransitive and a transitive one. The intransitive model views the origin of the world as a spontaneous growth, developing all of itself out of a primordial chaos or matter, mostly water. The transitive model takes the world to be the object of a constructive activity of a creator. In what follows, I shall refer to the intransitive model by the term "cosmogony" and to the transitive one by the term "creation". To us, creation, the transitive model, is the more familiar one, since it is shared by the three monotheistic religions, biblical and rabbinical Judaism, Christianity, and Islam. In ancient Egypt, the two models combine and interact in a rather complex manner. The first cosmogonic impulse is generally represented as a spontaneous process. Out of the primordial waters, a god arises. His name, Atum, signifies "non-being" and "complete being"; it is a typical example of what Sigmund Freud called "der Gegensinn der Urworte", the contrarious meanings of primal terms. ${ }^{1}$ The cosmogonical moment is when Atum turns from non-being into being, adopting in the act the shape of the sun and emitting, according to Egyptian conceptions, air and fire, i.e. the god of air, Shu, and the goddess of fire, Tefnut. From then on, the process of creation or cosmogony continues in the "biomorphic" form of begetting and giving birth and unfolds in four generations. This is the famous cosmogony of Heliopolis which, in Egypt, holds the place of a Great Tradition, all other cosmogonies and creation accounts (of which there are a great many) being just variations of and commentaries on this basic conception. Shu-air and Tefnut-fire beget Geb-earth and Nut-heaven, who in turn gives birth to

${ }^{1}$ Freud 2000, 227-34, a short article published in 1910 and based upon K. Abel, Über den Gegensinn der Urworte, 1884, which in its turn is dependent mostly upon Ancient Egyptian examples. 
five children: Osiris, Seth, Isis, Nephthys, and Horus. Horus, however, is also the child of Osiris and Isis, forming the fourth generation.

Atum is the only god who has no parents and came spontaneously into being. He is therefore called kheper-djesef, "the self-generated one", in Greek "autogenes". This idea of a self-generated primordial deity personifying the origin of the universe had an enormous influence not only within the three millennia of ancient Egyptian cosmo-theological speculations but far beyond. The terms autogenes and monogenes abound in the Hermetic, Neoplatonic and related writings. In the Heliopolitan cosmogony, his mode of generating Shu and Tefnut is depicted as an act of masturbation and ejaculation, or of coughing and spitting, all of which are images for the idea of motherless procreation. Since the Egyptians ascribed the same mode of procreation also to the scarabbeetle scarabaeus sacer, this animal became a symbol of the "autogenic" god. Creation through procreation is a "biomorphic" concept, which is closer to cosmogony than to creation. There is no planning and no goaldirected activity involved. Also the unfolding of a genealogy in four generations may be seen as a form of natural growth, rather than of technical construction.

The gods, however, interfere with creative acts into this natural process. Atum, having turned into the sun god Re and ruling his creation as the first king, decides after rebellious intentions against his rule by humankind to separate heaven and earth, to raise the sky high above the earth and to withdraw thither with the gods, leaving the kingship to his son Shu, who, being the god of the air, is perfectly fit for the task both of separating and connecting the spheres of gods and humans. The Egyptian story of the separation of heaven and earth has many parallels in the biblical story of the flood. In both cases, humankind is nearly annihilated and a new order is established which guarantees the continuation of the world under new conditions: in the Bible under the conditions of the Noachidic laws, in Egypt under the conditions of the state, which serves as a kind of church, establishing communication with the divine under the conditions of separation. The Heliopolitan cosmogony is at the same time what may be called a "cratogony": a mythical account of the emergence and development of political power. At the beginning, be-reshit, is kingship. Kingship or rulership is conceived of in Egypt as the continuation of creation under the conditions of existence. It is first exercised by the creator himself in a still state-less form of immediate rulership and passes from him to Shu, to Geb and to Osiris. With $\mathrm{Shu}$, it loses its immediate character and takes on the forms of symbolic 
representation, with Geb, the god of the earth, it becomes terrestrial and with Osiris, the god of the netherworld, it becomes political and historical. The line of succession describes a downward movement: from the sun via the air and the earth down into the netherworld. Moreover, it describes the transition from cosmogony to history, from the dynasties of the gods to the dynasties of human kings, from "deep time" to "historical time".

In the context of the Heliopolitan cosmogony, the central term is not "to create", in Egyptian jrj "to do, to create, to produce", but kheper, "to become, to take shape". Kheper refers to the ideas of transformation, emanation and evolution. The god transforms himself into an active, conscious being emanating air and light, from which then the other gods evolve. There is a clear distinction between what emanates or evolves from god's own substance and what is created out of external material. Typical of this thought are the metaphors of "secretion": the first gods were spat and coughed out, while men arose from the tears of god. ${ }^{2}$ Even when the "issuing from the mouth" is no longer understood as secretion, but as a speech act, the names of the gods arise, as it were, incidentally and certainly unintentionally from the conversations of the god with himself or the primeval waters from which he emerged. ${ }^{3}$

\section{Creation by Speech}

The creation by speech, or the speech act as a major means of creation, seems to be the great innovation of the New Kingdom, after some significant precursors in the Coffin Texts of the Middle Kingdom.

Let's listen to a creation account in a hymn to Amun-Re dating from about 1400 BCE:

He came forth as self-generated, all his limbs speaking to him He formed himself before heaven and earth came into being the earth being in the primeval waters in the midst of the "weary flood".

\footnotetext{
${ }^{2}$ CT VII 464-5; cf. also infra 1.4.

${ }^{3}$ Cf. the emergence of the "Eight Heh Gods" on the occasion of a conversation between Atum and Nun CT II 5-8; cf. Sauneron and Yoyotte 1959, 47.

${ }^{4}$ Or, with Zandee 1992, 36f.: "between these" ( $n n=$ demonstrative, referring to "heaven and earth"). The words, jmjtw nn, occur in a similar context in pLeiden I 344v., i, 7 .
} 
You have started to create this land to establish what has come from your mouth (= the gods)

You have raised heaven and kept earth down to make this land wide enough for your image

You have taken on your first form as Re to illuminate the Two Lands for that what you have created. as your heart [planned], you being alone You created them, the gods being in your retinue after you came forth alone from the primeval waters

You created humans together with creatures great and small and all that has come into existence and all that exists.

The text starts with the motif of self-generation (kheper-djesef). The god takes on bodily shape, and this body forms already the first pantheon: a community of limbs who start speaking with their god and master. According to this text, this sacred conversation took place already before the origin of the world. This is the first act of cosmogony. The second act is described as "creation", jr.t. The land is "created" for the gods who issued from the mouth of god, obviously in form of utterances. The third act is the separation of heaven and earth, leading to the establishment on earth of the divine image, i.e. the replacement of real presence by a representation. The whole process is then traced back to an act of willful planning preceding both cosmogony and creation. Before anything originates or is created, the world is already conceived in the heart of god. I call this idea "creation through the heart", the heart being the organ of planning and thinking according to Egyptian anthropology. This is an idea becoming more and more prominent in the course of time. Let me just quote a short selection of pertinent passages in order to illustrate the idea. Queen Hatshepsut praises the god Amun-Re as "he who devises (thinks, plans) everything that exists." The same epithet occurs in a short hymn to Re:

Re who planned everything that exists, lord of humankind, creator of what exists. ${ }^{6}$

You created the earth according to your will, you being alone.

${ }^{5}$ Zandee 1992, 99, 11. 15-16.

${ }^{6}$ BM 29944 ed. Steward, JEA 53,37.

7 Amarna ÄHG no. 92,79. 
The one who created the earth in the seeking (enquiring spirit) of his heart. ${ }^{8}$

The one who initiated everything

that exists as his heart planned. ${ }^{9}$

The one who created heaven and earth with his heart. ${ }^{10}$

Conspicuously frequent is this motif in hymns to Ptah, the god of Memphis:

The one who created the arts

and gave birth to the gods as a creation his heart. ${ }^{11}$

The one who created the arts

as a discovery of his heart. ${ }^{12}$

Who made heaven

as the creation of his heart. ${ }^{13}$

The things that are said (or "thought") in his heart one sees that they come into being. ${ }^{14}$

The one who formed the earth

by the providence of his heart. ${ }^{15}$

The activity of the heart, in planning, devising and conceiving, is obviously related to the way of working characteristic of the artists and craftsmen, whose patron is the god Ptah.

Besides planning, the most typical modes of creation are begetting, shaping and speaking. We have already dealt with the biomorphic model of begetting; it remains the most fundamental concept throughout Egyptian pharaonic history. The act of shaping or molding may be labeled as the technomorphic model. In Egypt, it is related to the god Khnum who is believed to form humans on a potter's wheel. Interestingly enough, in the Bible, man is also "formed" by god, whereas the rest of creation comes into being through god's commanding speech.

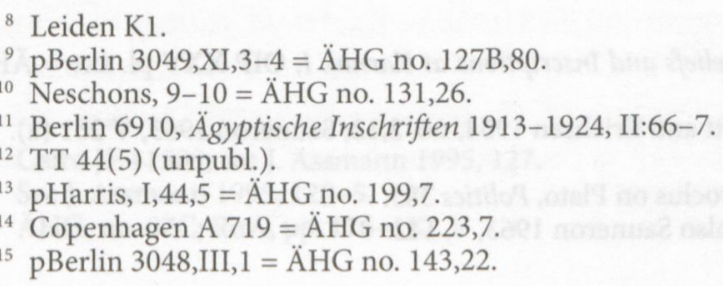


The third mode, speaking, gains enormously in prominence during the New Kingdom. In texts of the 15th and 14th centuries, speaking is still exclusively related to the creation of the gods. The gods are constantly referred to as having issued from the mouth of god. The concept of creative utterance does not in the first instance interpret the relationship of "god" to the world, but of "god" to the other gods.

To the creation of the gods by speech refers the very widespread motif that correlates the gods with the mouth or lips of the creator, and humans with his eyes. The gods originate by speaking, humans by weeping:

Humans issued from his eyes

the gods emerged on his mouth. ${ }^{16}$

Humans issued from his eyes,

the gods from his lips. ${ }^{17}$

He secreted everybody from his eyes,

but the gods issued from his mouth. ${ }^{18}$

Gods issued from his mouth

and humans from his eye. ${ }^{19}$

There are very many variants to this motif. The theme still plays an important role in Greco-Roman texts ${ }^{20}$ and is related, in a way that has yet to be explained, to the particularly Orphic $\mathrm{c}^{21}$ and generally Greek idea $^{22}$ that the gods issued from the laughter, humans from the tears of the primeval creator god. ${ }^{23}$

The relationship between tears and human beings in Egyptian texts is clearly based on the homophony of the words rmt (human beings) and rmjt (tears). But what could be the relationship between the gods and the speaking mouth? These gods embody the hidden verbal order of the world, as it were, its conception, as it was devised and uttered by "god," the one who, as it is expressed in a contemporary hymn,

${ }^{16}$ pCairo 58038,vi,3. prr.n must be a mistake; read prrw or pr.n.

17 STG Text no. 188 (e).

${ }^{18}$ RT 13, 163.16.

${ }_{19}$ Ramses III's hymn, Reliefs and Inscriptions at Karnak I, OIP XXV pl. xxv = ÄHG no. 196.

${ }^{20}$ Otto 1964, 58ff.; Schott and Erichsen 1954, no. 2,12; Sauneron 1963, V 261 (a).

${ }^{21}$ Orph. fr. 28 Abel.

22 Dieterich 1891, 28; Proclus on Plato, Politics 385.

${ }^{23}$ Esna no. 272,2-3; cf. also Sauneron 1963, V, 142. 
creates what is created,

who speaks, and the gods come into being. ${ }^{24}$

A similar formulation occurs in a longer text of fundamental importance for the theology of Amun in this period, Papyrus Boulaq 17 (= Cairo CG 58038), which contains hymns to Amun-Re. ${ }^{25}$ I shall cite the formulation in its context, which makes it clear that we are dealing with more than creation theology:

Hail to you, Re, lord of Maat,

who hides his chapel, lord of the gods,

Khepri in his barque,

who commands and the gods come into existence,

Atum, creator of humankind,

who distinguishes their characteristics and creates their means of subsistence,

who distinguishes their skin color, one from the other.

He who listens to the entreaty of one in distress,

gracious to one who calls to him,

who saves the timorous from the hand of the violent,

who pronounces justice between the poor and the rich.

Lord of cognition, on whose lips is creative word, for whose sake the Nile inundation comes;

the lord of affection, the great of love,

when he (i.e., the inundation) comes, humankind lives. ${ }^{26}$

The god from whose will and commanding utterance the other deities emerge is none other than the "lord of Maat," the supreme judge who "pronounces justice between the poor and the rich," "saves the timorous from the hand of the violent," and "listens to the entreaty of one in distress." This is clearly a god who speaks, not only as a creator who by his words brought the gods into being, but also as the maintainer of the universe who rules it by what the Egyptians call "Sia", cognition" and "Hu", authoritative and performative utterance. Hu and Sia are epithets both of the creator and of the ruler. Sia refers to the recognizing and devising heart, $\mathrm{Hu}$ to the speaking, ordaining and commanding mouth.

${ }^{24}$ Cairo JE 11509; see J. Assmann 1995, 127.

${ }^{25}$ See J. Assmann 1995, 120-5.

26 ÄHG, no. 87C; RuA, pp. 176-177. 
That the idea of a creation through the word is originally related to the divine world and not the world as such seems to me highly significative. The pantheon appears in this tradition as a speech act, an act of verbal articulation. The gods are articulations of reality, their names, competences, and powers give shape and differentiation to the diffuse experience of reality and makes it addressable. This mythology shows the structure of the divine world to be primarily linguistic.

In the later stages of the New Kingdom and during the Late period, however, the speaking mode of creation becomes generalized, referring now not only to the gods but to "everything that exists". For this idea, let me quote just one example from the tomb of the high-priest Nebwenenef dating from the first half of the 13th c.:

Who created heaven and earth and gave birth to human beings, who brought forth all that is through the utterance of his mouth. Who spoke and it happened, who gave birth to what exists, Great One, creator of the gods and human beings.

Who came into being alone and gave birth to himself as millions.

It was his limbs that answered him, it was his tongue that formed everything he created. ${ }^{27}$

The idea of verbal creation, according to a plan conceived in the heart, emphasized the organisational aspect of the created world, its rational character. What was conceived in the heart of god and came forth from his mouth were not the things themselves, but the "names of all things" ${ }^{28}$ which the Egyptians imagined to be arranged hierarchically in the form of an onomasticon. An onomasticon does not enumerate individual objects, but classes of objects. ${ }^{29}$ It can therefore be understood as an exhaustive inventory of the cosmos and a replica of its structure. The doctrine of verbal creation envisaged the well-appointed nature of the world, its fullness and order, and attributed them to the wisdom of the creator, the spiritual conception in the heart. This was an aspect of the world especially emphasised by Amarna religion, which also influenced Psalms 104 and Wisdom in Hebrew literature. ${ }^{30}$

27 STG, No. 149 p. $188 \mathrm{f}$.

${ }^{28}$ Memphite Theology 55; similarly pBerlin 3055 XVI 3ff. = ÄHG no. 122,7.

${ }^{29}$ This is true of entities such as "heaven", "sun", "moon" "king", which have to be understood as one-element classes.

${ }^{30}$ Cf. n. 1. 


\section{Creation through Hieroglyphs in the Memphite Theology}

The Memphite Theology has always been interpreted as the closest Egyptian parallel to the Biblical idea of creation through the word. ${ }^{31}$

The gods that originated from Ptah/became Ptah (...)

originated through the heart as symbol of Atum, originated through the tongue as symbol of Atum, being great and powerful.

But Ptah transferred [his strength]

to the gods and their $k a$ 's

by means of this heart through which Horus originated from Ptah, by means of this tongue through which Thoth originated from Ptah.

It came to pass that heart and tongue gained power over all other parts on the basis of the teaching that it [the heart] is in every body and it

[the tongue] in every mouth of all gods, humans, animals, insects, and all living things, the heart thinking and the tongue commanding whatever they desire.

In the guise of tongue and heart a portion of Ptah's original creative power remains in all living things that have come forth from him. An anthropological discourse now beings:

His Ennead stood before him as teeth, that is the seed of Atum, and as lips, that is the hands of Atum. Verily, the Ennead of Atum originated through his seed and through his fingers. But the Ennead is in truth teeth and lips in this mouth of him who thought up the names of all things, from whom Shu and Tefnut came forth, he who created the Ennead.

This section of the Theology has always been interpreted as a polemical engagement with Heliopolis. However, it seems to me much more convincing to read it as a commentary, in which the ancient, supra-regionally valid teachings are specifically related to Memphis. The "seed" and "hands" of Amun, by which in an act of self-begetting he brought forth Shu and Tefnut, are interpreted as "teeth" and "lips," forming the frame for the tongue that creates everything by naming it:

${ }^{31}$ Cf. Koch 1988, 61-105. 
That the eyes see, the ears hear, and the nose breathes air is in order to make report to the heart. This it is that makes all knowledge originate.

The tongue it is that repeats what is thought by the heart.

The process of creation is here conceived in bodily terms. "Phallus" and "hand" - the traditional physical symbols of creativity-are represented as or replaced with "teeth and lips." The genuinely creative organs are heart and tongue. As the Egyptians made no strict distinction between "body" and "mind/spirit," knowledge and language are also understood as bodily phenomena. Knowledge originates in the heart on the basis of the perceptions reported to it. The knowledge formed in the heart is communicated by the tongue.

And thus were all gods born,

that is Atum and his Ennead.

But all hieroglyphs originated

from that which was thought up by the heart and commanded by the tongue.

And thus were all $k a$ 's created and the Hemuset determined, which bring forth all food and all offering meats by this word, [the word invented by the heart and commanded by the tongue].

[And thus is ma'at given to him] who does what is loved, [and isfet to him] who does what is hated.

And thus is life given to the peaceable and death given to the criminal.

And thus were all trades created and all arts, the action of the arms and the walking of the legs, the movement of all limbs in accordance with the instruction of these words that were thought up by the heart and uttered by the tongue and provide for all things. (...)

And so Ptah was well pleased (or: rested) after he had created all things and all hieroglyphs, after he had formed the gods, after he had created their towns and founded their names, after he had endowed their offering cakes and established their chapels, after he had created their bodies [= images of them] in their likeness, such that they were content.

And thus the gods entered their bodies of every kind of wood and mineral,

all kinds of clay and all other things that grow on him from whom they originated.

And thus assembled around him all gods and their $k a$ 's, content and united with the lord of the two lands. 
This is the most elaborate Egyptian account of creation by the Word, and it differs from the Biblical account in two ways. The first is the role of the heart, i.e. the planned conception of creation-an idea absent from the Bible. The second is the role of script, the hieroglyphs, mentioned on two occasions. These two points are closely related. For what the heart thinks up are not the names of things but their "concepts" and their "forms." Hieroglyphic script is a pictorial rendering of the forms. It relates to the concepts by way of those forms. The tongue vocalizes the concepts, which were "thought up" by the heart and given outward and visible form by hieroglyphic script:

But all hieroglyphs originated

from that which was thought up [conceived of] by the heart and commanded by the tongue.

Ptah is the god of artists and craftsmen, the one who endows things with their "design," their immutable form depicted by the written signs. Thus Thoth, the god of the "tongue," is also the god of hieroglyphic script. $\mathrm{He}$ is able to transform the thoughts of the heart into spoken and written language. Creation is an act of articulation - conceptually, iconically, phonetically. The written signs originate at the same time as the things they stand for and the names they bear:

And so Ptah was well pleased after he had created all things and all hieroglyphs.

The totality of creation is encompassed in the term "all things and all hieroglyphs." The Egyptian word for "hieroglyphs", which the Greeks translated as ta hiera grammata is $z S n m d w n T r$ "the writing of divine speech". ${ }^{32}$ Thoth, the god of writing, is called "the lord of divine speech". ${ }^{33}$ The sacred texts which were written in hieroglyphs are called "scrolls of divine speech". ${ }^{34}$ Thus it is quite evident that "divine speech" refers to the signs (and not to the sounds), which Thoth commands, which the sacred books contain and which constitute the sacred script.

If the distinction between a sphere of original forms (Ideas) and a world of infinitely reproduced copies is a principle of Plato's philosophy, then the Egyptian division of Creation expresses a primal, pre-theoretical Platonism. The hieroglyphs are the forms of the things that constitute

$32 \mathrm{~Wb}$ II, 181.2.

${ }^{33} \mathrm{~Wb}$ II, 181.6.

${ }^{34}$ Wb II, 181.1. 
the totality of the real world. Egyptian "hieroglyphic" thinking presents a relation between thing and written sign similar to that between thing and concept in Greek philosophy. When Ptah conceives of the Ideas of things, he at the same time invents the script that Thoth has only to read. The act of thinking or conceptual articulation is represented in this mythology as an act of interior writing. The act of speaking, on the other hand, is conceived of as an act of reading aloud, reciting the inner script. The speaking tongue, or Thoth, recites what the thinking heart, or Horus, writes. However, Thoth appears in this mythology not only as a reciter but also as a copyist. Thoth, the god of script, only has to find, not invent, what is inherent in the structure of things. He copies the interior writing of the heart onto papyrus. Thus an onomasticon, a list of words arranged not alphabetically but in an order reflecting the structure of reality, is titled as a catalogue of "all things that exist: what Ptah created, what Thoth copied down."35

The collaboration between Ptah, who creates all things, and Thoth, who records them, is reminiscent of the collaboration between God and Adam in Paradise. God creates living things and "Adam gave names to all cattle, and to the fowl of the air, and to every beast of the field" (Gen. 2:20). Adam's act of naming and Thoth's act of recording both fulfill the same function of linking things and words. And as this is creation by the Word, Adam and Thoth both "read" from the created things what they then utter or record.

In his Mysteries of the Egyptians, the neo-Platonist Iamblichus perceptively identifies the latent Platonism of hieroglyphic thinking in his interpretation of Egyptian script as an imitation of divine "demiurgy":

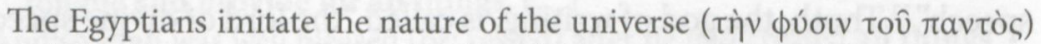

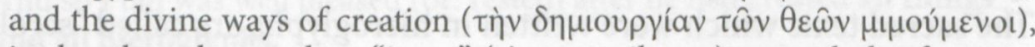
in that they also produce "icons" (Eikovac eikonas) as symbols of mystic,

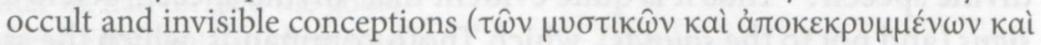
$\dot{\alpha} \phi \alpha v \hat{\omega} v v$ vó $\sigma \varepsilon \omega v$ ), in a similar manner as of Nature (the productive principle), in her peculiar way, makes a likeness of invisible principles through

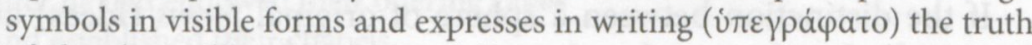
of ideas by visible icons (Eikovec). ${ }^{36}$

"Nature" ( $\varphi$ voøৎ) takes here the place of Ptah in the Memphite Theology. Like Ptah, nature conceives "invisible principles" and expresses them

${ }^{35}$ Gardiner 1947, I, *1.

${ }^{36}$ Iamblichus, De Mysteriis, VII.1. 
through symbols in visible form. The world as we see it is the visible expression of an invisible conception. The Egyptians imitate this procedure in their hieroglyphic script. In using the visible forms of nature for letters, they refer to invisible principles, i.e. to meanings. If god or nature created the world by inventing signs, the Egyptians imitate this device by using these signs for their script.

\section{Cosmic Grammatology}

The creation account of the Memphite Theology teaches us, therefore, above all two things: one regarding the conception of the cosmos and another regarding the conception of hieroglyphs. It stresses the "scriptural" structure of the cosmos and the "cosmic" structure of the hieroglyphic signs. Let me first explain what I mean by the scriptural structure of the cosmos. All creation accounts that view the world as generated by verbal articulation presuppose a structural analogy between language and cosmos. The late-Egyptian account, however, goes even a step further in conceiving of the world as the result not only of an act of speech but of writing. It presupposes an analogy between cosmos and writing and establishes a relationship not only between res and verba but between res and signs. In the Biblical creation account, god speaks and the world appears. In the Egyptian text, god first conceives the signs in his heart and only then, in a second step, expresses them in phonetic language. In the Bible, we have the two-step procedure from verba to res, in Egypt we have three steps: from signs via verba to res. It is only with the rabbinic commentary on Genesis, Bereshit rabbah, that the Biblical conception of the creation is also extended to a three step procedure. In this text, the phrase be-reshit is interpreted not as "in the beginning" but "by means of the beginning", and the beginning is identified as the Torah. God created heaven and earth by means of the Torah: be-reshit = be-torah. First there was Torah, a universe of signs, which God only had to read aloud in order to create a universe of things. The Torah here plays the role of a preexistent script or blueprint of the universe which God only had to read out in order to create the world.

If we consider the iconic character of hieroglyphs, the analogy between writing and cosmos becomes obvious. It is much more evident to postulate a correlation between the iconic signs of the hieroglyphic script and the things of reality than between the words of language and the things of nature. The relationship of hieroglyphic signs to the world seems 
much more direct than the relationship of words to what they denote. To use a term coined by Aleida Assmann, we may speak, with regard to hieroglyphs, of "immediate signification". ${ }^{37}$ The iconic sign immediately shows what it means, without the detour of a specific language. To be sure, this is not the way hieroglyphs normally function, but it is a plausible assumption about hieroglyphs, given their pictorial character, and it is this assumption that underlies the creation concept of the Memphite Theology. The only difference between a stock of iconic signs and a stock of existing things is the number. The set of signs is necessarily much smaller than the set of things. But this is exactly what the late Egyptian priests and grammatologists strived at correcting. They extended the stock of signs by approximately a factor 10 , turning a well functioning script of about 700 signs into an extremely difficult and awkward system of about 7,000 in order to make the script correspond as closely as possible to the structure of reality: a universe of signs representing a universe of things, and vice-versa. By approximating the number of signs to the number of things, the late Egyptian priests stressed the cosmic structure of their script as well as the grammatological or scriptural structure of their universe.

However, immediate signification is precisely what the Bible shuns as idolatry. Already the church fathers recognized the idolatrous character of the hieroglyphic script and destroyed the Egyptian temple schools because they considered them to be schools of magic. In the Renaissance, Giordano Bruno made the same connection but inverted the valuation. Hieroglyphs were the superior script because of their magical power, which derived from their principle of immediate signification:

....the sacred letters used among the Egyptians were called hieroglyphs... which were images...taken from the things of nature, or their parts. By using such writings and voices, the Egyptians used to capture with marvellous skill the language of the gods. ${ }^{38}$

${ }^{37}$ A. Assmann 1980. See also Greene 1997, 255-72. In exactly the same sense as A. Assmann, Greene distinguishes between a "conjunctive" and a "disjunctive" theory of language. Cf. also Tambiah 1968, 175-208.

${ }_{38}$ Giordano Bruno, De Magia (Opera Latina III, 411-12), quoted after Yates 1964, 263. The connection between hieroglyphics and magic is provided by the church historian Rufinus who reports that the temple at Canopus has been destroyed by the Christians because there existed a school of magic arts under the pretext of teaching the "sacerdotal" characters of the Egyptians (ubi praetextu sacerdotalium litterarum (ita etenim appellant antiquas Aegyptiorum litteras) magicae artis erat paene publica schola; Rufinus, Hist.eccles. XI 26). 
Bruno is clearly thinking of Iamblichus and what he has to say about the Egyptian ways of imitating in their script the demiourgia of the gods. Still, one wonders how closely he comes to the Egyptian term designating the hieroglyphs: $m$ d.t nature, divine speech, language of the gods.

Some 150 years later, the Anglican bishop William Warburton made the same connection between hieroglyphs and idols. ${ }^{39}$ As Warburton pointed out, the second commandment forbids not only the representation of God because he is invisible and omnipresent, ${ }^{40}$ but also the making of "any graven images, the similitude of any figure, the likeness of male or female, the likeness of any beast that is on the earth, the likeness of any winged fowl that flies in the air, the likeness of anything that creeps on the ground, the likeness of any fish that is in the waters beneath the earth" (Dt. 4.15-18, Warburton's translation). Images are idols because by virtue of 'immediate signification' they conjure up what they represent. Hieroglyphs are idols because they are images. Warburton's interpretation emphasizes the anti-Egyptian meaning of the prohibition of idolatry. It is the exact "normative inversion" of the very fundamental principles of Egyptian writing, thinking, and speaking: "Do not idolize the created world by < hieroglyphic > representation." The second commandment is the rejection of hieroglyphic knowledge because it amounts to an illicit magical idolization of the world.

The second commandment is, at least originally, directed against all kinds of magic, necromancy, divination and other religious practices operating with images. Precisely this magical power is connected, in the Late Egyptian imagination and far beyond, with the hieroglyphic script which they call "god's words" or "divine speech". Their magical power lies in their "cosmic structure", corresponding to the "scriptural" or hieroglyphic structure of the cosmos. This magical conception of hieroglyphic writing, the Egyptians handed down to the Greeks who, in their turn, handed it down to the renaissance and Enlightenment. Hieroglyphs were regarded as "natural signs", a "scripture of nature," a writing which would refer not to the sounds of language, but to the things of nature and to the concepts of the mind. To quote Ralph Cudworth's definition: "The Egyptian hieroglyphicks were figures not answering to sounds or words, but immediately representing the objects and conceptions of the mind." 41

${ }^{39}$ See J. Assmann 2001, 297-311.

${ }^{40}$ Cf. Halbertal and Margalit 1982, 37-66 ("Idolatry and Representation").

${ }^{41}$ Cudworth 1678, 316. 
However, we may not draw too sharp a distinction between writing and language. The two are constantly confounded, by the Egyptians, the Greeks and by Europeans well into the 18th century. The Egyptian term $m$ d.t $n T r$, literally meaning "divine speech", refers not only to hieroglyphs but also to what the Hebrews would call d'barej ha-Elohim. If there is any Egyptian specificity, it lies in the particularly strong association of script and language. Md.t nTr "divine speech" means "hieroglyphs", it is true, but the orally spoken word of the gods is also of enormous importance. Whenever a god opens his mouth, we may be sure that something very important comes forth, an irrevocable order, an institution which is still existing, a being, a rite, an element of reality. A divine word becomes immediately reality, even independent of any conscious intention of the speaker, by way of pun or assonance or whatever association. The utterance is treated as another bodily secretion such as blood, sweat, semen, saliva-all of them generating various things. The divine word appears here rather as a kind of sonoric/semantic substance containing not just one, but all possible meanings which may be associated with its homonyms, antonyms, its connotations and assonances without being limited by any intention, syntax or context. The constructive creativity of divine words unfold under the conditions of deconstruction. Divine speech is over-determined like the symbolism of dreams according to Freud.

In consequence of the typical non-distinction between script and language, Iamblichus applies the characteristic of the Egyptian sacred script, i.e. hieroglyphs, to the Egyptian sacred language. If hieroglyphs refer "immediately", that is iconically, to reality, the words of the sacred

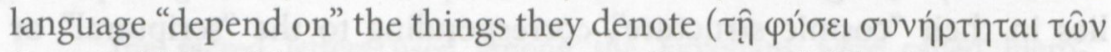

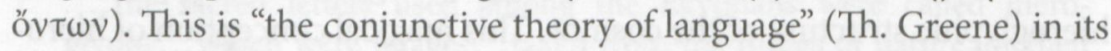
purest form. Treatise XVI of the Corpus Hermeticum forbids the translation into Greek of texts in the sacred language in rather violent terms:

Preserve this discourse untranslated in order that such mysteries may be kept from the Greek and that their insolent, insipid and meretricious manner of speech may not reduce to impotence the dignity and strength of our language, and the cogent force of the words. For all the Greeks have... is empty speech, good for showing off; and the philosophy of the Greeks is just noisy talk. For our part, we use not words, but sounds full of energy

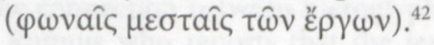

${ }^{42}$ Festugière and Nock 1945, II:232; Fowden 1993, 37. 
Instead of "sounds" (phonais), we may as well read "signs". The Egyptians were convinced of the power of language, not only in spoken but above all in written form. This is the reason why they never changed or reduced the pictorial realism and the iconic character of the hieroglyphs. They would rather invent, at first a second and then a third script alongside the hieroglyphs than adapt the hieroglyphs to everyday purposes. In their iconity lay their cosmological character which corresponded to the "grammatological" structure of the cosmos.

\section{REFERENCES}

Ägyptische Inschriften 1913-1924. Ägyptische Inschriften aus den Königlichen Museen $z u$ Berlin. Herausgegeben von der Generalverwaltung. Leipzig: Hinrichs.

Assmann, A. 1980. Die Legitimität der Fiktion, Munich.

Assmann, J. 1995. Egyptian Solar Religion in the New Kingdom: Re, Amun and the crisis of polytheism. Tr. A. Alcock, New York: Kegan Paul.

2001. "Pictures versus Letters: William Warburton's Theory of Grammatological Iconoclasm." in Representation in Religion: Studies in Honor of Moshe Barasch, ed. J. Assmann and A. Baumgarten, Leiden: Brill, 297-311.

Cudworth, R. 1678. The True Intellectual System of the Universe: the First Part, wherein All the Reason and Philosophy of Atheism is Confuted and its Impossibility Demonstrated. 1st ed. London: 1678; 2nd ed. London: 1743.

Dieterich, A. 1891. Abraxas: Studien zur Religionsgeschichte des späteren Altertums. Leipzig: Tuebner.

Erichsen, W. and S. Schott 1954. Fragmente memphitischer Theologie in demotischer Schrift (Pap. demot. Berlin 13603), Mainz: Akademie der Wissenschaften und der Literatur.

Festugière, A.J. and A.D. Nock 1945. Corpus Hermeticum, Paris, Société dédition "Les Belles lettres".

Fowden, G. 1993. The Egyptian Hermes: a historical approach to the late pagan mind, Princeton: Princeton University Press.

Freud, S. 2000. "Über den Gegensinn der Urworte," Studienausgabe Frankfurt, vol. $4: 227-234$.

Gardiner, A.H. 1947. Ancient Egyptian Onomastica, London: Oxford University Press.

Greene, T.M. 1997. "Language, Signs and Magic", in Envisioning Magic: a Princeton Seminar and Symposium, ed. P. Schäfer and H.G. Kippenberg, Leiden, New York: Brill.

Halbertal, M. and A. Margalit 1982. Idolatry, Cambridge, Mass: Harvard University Press.

Koch, K. 1988. "Wort und Einheit des Schöpfergottes in Memphis und Jerusalem. Zur Einzigartigkeit Israels," Studien zur alttestamentlichen und altorientalischen Religionsgeschichte: zum 60 Geburtstag von Klaus Koch, ed. E. Otto, Göttingen: Vandenhoeck and Ruprecht.

Nelson, H.H. 1936. Reliefs and Inscriptions at Karnak I, Oriental Institute Publications XXIV, Chicago: University of Chicago Press.

Otto, E. 1964. Gott und Mensch nach den ägyptischen Tempelinschriften der griechischrömischen Zeit; eine Untersuchung zur Phraseologie der Tempelinschriften, Heidelberg: Winter.

Sauneron, S. 1963. Le temple d'Esna, Cairo: Institut français d'archéologie orientale.

Sauneron, S. and J. Yoyotte 1959. "La Naissance du monde selon l'Égypte ancienne." 
In La Naissance du monde; Égypte ancienne, Sumer, Akkad, Hourrites et Hittites, Canaan, Israel, Islam, Turcs et Mongols, Iran préislamique, Inde, Siam, Laos, Tibet, Chine. Sources Orientales I, Paris: Editions du Seuil, 17-91.

Tambiah, S.J. 1968. "The Magical Power of Words," Man, n.s. 3:175-208.

Yates, F. 1964. Giordano Bruno and the Hermetic Tradition, Chicago: University of Chicago Press.

Zandee, J. 1992. Der Amunshymnus des Papyrus Leiden I 344, Verso, Leiden: Rijksmuseum van Oudheden. 